\title{
Diet composition of goats grazing in mixed shrubs-grass rangeland
}

\author{
A.S. NASTIS \\ Range Sci. Lab. 236, Aristotelion University, 54006 Thessaloniki (Greece)
}

\begin{abstract}
Measurements of time spent by goats grazing shrubs or herbaceous species (relative palatability) on a continuous grazed pasture were made in a herd of 32 local goats from $8: 30$ until 13:00 hrs the first 2-3 days of each month, all the year found. Periodically, the herd was placed in an ungrazed section of the pasture and similar measurements were obtained. The species present expressed as a percent of cover during May were : Quercus coccifera $(54 \%)$, Carpinus duinencis $(3 \%)$, Fraxinus ornus $(2 \%)$, Cistus incanus $(9 \%)$, Dactylis glomerata $(7 \%)$, Festuca ovina $(2 \%)$, legumes $(10 \%)$, etc. The average forage production was $2460 \mathrm{~kg} / \mathrm{ha} /$ year $(57 \%$ shrubs, $43 \%$ herbage). The stocking rate was $0.5 \mathrm{AUM} / \mathrm{ha}$.
\end{abstract}

In the continuously grazed section, during May when a broad array of species was available, relative palatability by groups of species was in the following order : Evergreen shrubs (ES) $22 \%$, gramineae (GR) $20 \%$, broad-leaved herbaceous species (BH) $28 \%$ and deciduous shrubs and trees (DS) $29 \%$. In July, when herbaceous species were mature and their supply was limited, relative palatability for the above mentioned groups of species was in the following order : ES $74 \%$, GR $11 \%$, BH $12 \%$, DS $3 \%$. The relative palatability for the same groups in October and December was : ES $88 \%$, GR $3 \%$, BH $8 \%$, DS $1 \%$ and ES $90 \%$, GR $3 \%$, BH $7 \%$, DS $0 \%$, respectively.

When animals were placed in the ungrazed section of the pasture where substantial amount of herbaceous species production was present, relative palatability was similar in May. The relative palatability ratings were : 1) in July ES $38 \%$, GR $28 \%, \mathrm{BH} 41 \%$, DS $4 \%, 2$ ) in October ES $54 \%$, GR $20 \%$, BH $25 \%$, DS $1 \%$ and 3) in December ES $74 \%$, GR $13 \%$, BH $13 \%$, DS $0 \%$, respectively.

Herbaceous species were relatively more palatable from shrubs from March to September given that both were available. There was only an exception during the period of rapid twig elongation in May when shrubs were equally palatable to herbage. During the remaining months (October through February) shrubs were more palatable even when a relative abundance of dry herbage existed. This was mainly a result of the low quality after maturation rather than the availability of the herbaceous species.

Relative palatability for the four groups of species was not significantly associated with availability $(P \leqslant 0.05)$. When availability was taken into consideration proportionally more time was spent for grazing broad-leaved shrubs in Spring, herbaceous species in Summer and regrowth of gramineae in Winter. It can be concluded that goats are adaptable mixed feeders rather than browsers even in a Mediterranean zone shrubland.

Key words : Goat, feeding behaviour, rangeland, shrub, grass.

\section{Influence of the kind of compound feed on goat milk production and composition}

\author{
Sylvie GIGER, D. SAUVANT, J. HERVIEU
}

Station de Nutrition et Alimentation (INRA), Institut National Agronomique Paris-Grignon, 16, rue Claude-Bernard, 75231 Paris Cedex 05

Milk composition influences cheese quality and is related to genetic and nutritional of feeding parameters. Present work deals with the influence of the carbohydrate nature of the concentrate on milk fat and protein content. 
Three couples of compound feeds were formulated with the same a priori organic matter digestibility (about $80 \%$ ) and protein content. Within each couple, blend $\mathrm{R}$ was as rich as possible in digestible fibre (mean crude fibre value : $15.7 \%$ dry matter) and the other one (P) was as poor as possible in those fibres and contained a maximum of starch (mean crude fibre value $6.6 \%$ dry matter). The concentrate was given according to milk production : $350 \mathrm{~g}$ dry matter per kilogram fat corrected milk : it was offered in combination with two kinds of very different forages (lucerne hay and maize silage).

The 124 data concerned only situations where the level of forage refusals was at least $10 \%$ The statistical analyses were performed for each basal diet using as a co-variable the measured energy balance expressed as grams of digestible organic matter (DOMB).

\section{TABLE 1}

Influence of nutritional parameters on milk composition and fat composition.

\begin{tabular}{|c|c|c|c|c|c|c|}
\hline Basal diet & \multicolumn{2}{|c|}{ Lucerne hay } & \multicolumn{2}{|c|}{$\begin{array}{c}\text { Lucerne hay }+ \\
\text { maize silage }\end{array}$} & \multicolumn{2}{|c|}{ Maize silage } \\
\hline \multirow[t]{2}{*}{ Number of observations } & \multicolumn{2}{|c|}{54} & \multicolumn{2}{|c|}{48} & \multicolumn{2}{|c|}{22} \\
\hline & R-P & Covariate & R-P & Covariate & R-P & Covariate \\
\hline Fat production (g/day) & $1.26 \mathrm{NS}$ & + & $13.56 \mathrm{NS}$ & ++ & $-8.63 \mathrm{NS}$ & NS \\
\hline Fat content $\ldots \ldots \ldots$ & $0.79 \mathrm{NS}$ & + & $2.56 \mathrm{NS}$ & ++ & $-1.53 \mathrm{NS}$ & NS \\
\hline Protein content $\ldots \ldots \ldots$ & $0.96 \mathrm{NS}$ & NS & $0.83 \mathrm{NS}$ & ++ & $1.15 \mathrm{NS}$ & NS \\
\hline$\% \mathrm{C} 4-\mathrm{C} 14 \ldots \ldots \ldots$ & $-1.63 \mathrm{NS}$ & $+t$ & $0.92 \mathrm{NS}$ & ++ & $-1.26 \mathrm{NS}$ & NS \\
\hline$\% \mathrm{C} 16 \ldots \ldots$ & $3.48++$ & ++ & $0.90 \mathrm{NS}$ & ++ & $0.15 \mathrm{NS}$ & NS \\
\hline$\% \mathrm{C} 18: 0+\mathrm{C} 18: 1 \ldots$ & $-2.52 \mathrm{NS}$ & ++ & $-1.56 \mathrm{NS}$ & ++ & $1.93 \mathrm{NS}$ & + \\
\hline
\end{tabular}

Level of significance : 1 p. $100^{* *} ; 5$ p. $100^{*}$.

The energy balance had a negative effect on the tested parameters but the type of concentrates, within a given forage, had no influence on milk composition and level of fat produced (tabl. 1). However, these results seem to point out that blend « $R$ » might slightly increase the milk fat or protein content and the fat production level in comparison to starch diets. The milk fatty acid composition was also measured and the statistical analysis was performed with 3 acid groups (sum $\mathrm{C} 4$ to $\mathrm{C} 14, \mathrm{C} 16$ and sum $\mathrm{C} 18: 0+\mathrm{C} 18: 1$ ) expressed as per cent fat or as levels of production per liter of milk or per day and per goat. Except in the case of per cent of C16 or production of $\mathrm{C} 16$ /liter of milk, there was no significant effect of the type of concentrate.

In conclusion, it appears that the nature of the concentrate had no specific influence goat milk composition or on the fat production.

Key words : Goat, milk composition, fibre, starch.

\section{Influence of dietary organic matter digestibility on goat nutrition and production at the onset of lactation}

\section{SAUVANT, J. HERVIEU, Sylvie GIGER, Françoise TERNOIS, Nadine MANDRAN, P. MORAND-FEHR}

Station de Nutrition et Alimentation (INRA), Institut National Agronomique Paris-Grignon, 16, rue Claude-Bernard, 75231 Paris Cedex 05

The negative energy balance of goats after parturition has drawn our attention upon its practical significance. Three diets (A, B, C) were given to 30,38 and 59 goats respectively of 